\title{
What Effect Does the Corona Virus Have on Various Organs?
}

\section{Review Article}

Volume 3 Issue 1- 2022

\begin{abstract}
Author Details
Mohammad Yavari ${ }^{1}$, Khatereh Skokri², Soheil Nasiri ${ }^{3}$, Zahra Nasiri Rad ${ }^{4}$, Fatemeh Ali Beigi ${ }^{5}$, Elham sharei ${ }^{6}$, Mahdiye Aghamohammadi ${ }^{7}$, Seyed alireza atapoor fard ${ }^{8}$, Maryam shahriari ${ }^{9}$, Hossein Esmaeilit ${ }^{10 *}$

${ }^{1}$ Bachelor of Science in Nursing, Islamic Azad University Tehran Branch, Tehran, Iran

${ }^{2}$ Bachelor of Science in Nursing, Islamic Azad University Semnan Branch, Semnan, Iran

${ }^{3}$ Bachelor of Science in Nursing, Islamic Azad University Semnan Branch, Semnan, Iran

${ }^{4}$ Bachelor of Science in Nursing, Islamic Azad University of Varamin, Tehran, Iran

${ }^{5}$ Bachelor of Science in Nursing, Islamic Azad University Qazvin Branch, Qazvin, Iran

${ }^{6}$ Bachelor of Science in Nursing, Islamic Azad University Tehran Medical Branch, Tehran, Iran

${ }^{7}$ Bachelor of Science in Nursing, Mashhad Medical science, Islamic Azad University Mashhad Branch, Mashhad, Iran

${ }^{8}$ Bachelor of Science in Nursing, Islamic Azad University Qazvin Branch, Qazvin, Iran

${ }^{9}$ Bachelor of Science in Nursing, Islamic Azad University Tehran Branch, Tehran, Iran

${ }^{10}$ Medical Student, Department of Medicine, Islamic Azad University Tehran Medical Sciences, Iran
\end{abstract}

*Corresponding author

Hossein Esmaeili, Medical Student, Department of Medicine, Islamic Azad University Tehran Medical Sciences, Iran

Article History

Received: January 20, 2022 Accepted: January 21, 2022 Published: February 02, 2022

\begin{abstract}
The new coronavirus does not only attack the lungs; The heart, kidneys, brain, arteries, nerves, and skin are other organs that have been shown to be affected by the new virus and their function.

Much has been written about the fact that Covid 19 lung disease affects the lungs and airways the most. Because the disease most commonly affects the lower respiratory tract, patients with moderate to severe disease, especially those with a dry cough, struggle with one of two problems: They have trouble breathing or pneumonia.
\end{abstract}

But articles show that the virus affects not only the lungs but also other organs such as the heart, brain, pancreas, liver, and bone.

Keywords: Covid-19; Effect covid-19; Nerves covid-19; Kidney covid-19

\section{Introduction}

Infection with the new Corona virus (SARS-CoV-2) was first reported in China in December 2019 and then spread rapidly to other parts of the world. On December 31, 2019, the World Health Organization (WHO) for the first time informed people about pneumonia of unknown origin in Wuhan City (Hubei Province, China) to people who epidemiologically sell to a local market of seafood and wet animals in Wuhan Were related, informed. Coronavirus (COVID-19) (2019corona virus disease) spread rapidly in most countries of the world after China, and on March 11, 0202, the World Health Organization declared it a pandemic [1], the third most common disease. It was human and animal [2].

Coronavirus is a group of single-stranded non-branched RNApositive round viruses belonging to the family Coronaviridae and
Nidovirales with four subfamilies: AlphaCoV (AcoV), BetaCoV (BcoV), DeltaCoV (DcoV) and GammaCoV [3].

CoV-OC-43 and CoV-229E as pathogens in humans and responsible for two viral diseases of beta-coronavirus (BcoVs) Middle East Respiratory Syndrome (MERS-CoV) [4,5] and Acute Respiratory Syndrome (SARS-CoV) [6,7]. The current epidemic of coronavirus (SARSCoV-2) has created a unique (unprecedented) health crisis. [8].

COVID-19 has directly or indirectly affected the entire human population. Directly causing a range of disorders from no symptoms to death and indirectly leading to illness or loss of a family member or socio-economic turmoil due to limited movement of packages and individuals [9]. The estimated percentage of people who will experience the symptoms of the disease with infection can be up to $50-80 \%$ of the world's population [10]. The disease mortality rate is currently approximately $3-4 \%[11]$. 
The clinical and pathological manifestations of COVID-19 are very similar to SARS and MERS $[2,12$,]. In addition to acute respiratory infections, CoVs are neuroinvasive and cause inflammation and nerve damage $[13,14]$ leading to nerve damage. Multiple sclerosis and encephalomyelitis $[15,16]$. This report also applies to neurological manifestations in patients (COVID-19) throughout the body including the epithelium of the respiratory tract, lung parenchyma, heart, vascular endothelium, gastrointestinal tract and system. Central Nervous System (CNS) is distributed [8]. An autopsy revealed the presence of viral RNA and the SARS-CoV-N protein in the small intestine, liver, sweat glands, parathyroid, stomach, kidney, pituitary gland, and brain, confirming the ability of SARS-CoV to cause systemic infection $[17,18]$. CoVs can cause extrapulmonary damage in children such as myocarditis, severe diarrhea, and multiorgan failure [19-24].

\section{Coronavirus is a Highly Functional Virus}

SARS-CoV-2 was initially thought to be a respiratory virus, but now available evidence suggests that it may be independently associated with severe inflammatory reactions on various organs (e.g., heart, liver, kidney, Gastrointestinal tract and nervous system) Common symptoms COVID-19 fever [68.0\%], dry cough [74.9\%], lethargy, sore throat and body aches, headache (30\% to $45.5 \%$ ) 2), shortness of breath [60.9\%], nasal congestion, conjunctivitis [26.2\%], taste disturbance (88\%) and olfactory (85.6\%) Acute Kidney Damage (AKI) is $40 \%$. A small number of patients had diarrhea and vomiting [2547]. Although the symptoms disappear in about 5 weeks on average, in some people the symptoms persist for 2 months or more. Nervous signs and symptoms related to central nervous system attack [48] appear simultaneously with respiratory symptoms or alone. Clinical studies report olfactory and taste dysfunction as the most common symptom in patients with COVID-19 [49]. Women are significantly more affected by olfactory and taste disorders than men [50]. In a study [51], gastrointestinal symptoms in $23.6 \%$ of patients had respiratory symptoms in $44.3 \%$ of cases and $32.1 \%$ in respiratory and gastrointestinal symptoms. However, older people are prone to severe infections including pneumonia, shortness of breath, and acute respiratory distress syndrome, resulting in higher mortality [8].

There is compelling evidence that SARS-CoV 2 can affect the nervous system through nerve damage and changes. The olfactory pathway and cranial nerves are the most logical explanation for an attack on the CNS. [52] Neurotropic viruses have developed mechanisms to escape host immune monitoring to access the CNS. Primary infection of neurons leads to acute cell dysfunction, which can lead to fatal encephalomyelitis. SARS-CoV-2 $[53,54]$. It can also damage the spinal cord and lead to acute myelitis $[4,55]$. The neurological symptoms in acute disease are far greater [44]. Preliminary reports indicate that neurological disorders are associated with the severity of SARS-CoV-2 infection, which includes loss of mind (cognitive impairment and impaired consciousness), olfactory and visual impairment, headache, dizziness, delirium, and pain. Nervousness, encephalopathy, ataxia and seizures, acute and ischemic stroke, cerebral venous thrombosis, paresthesia, neuropathy, movement disorders and intracranial infection [8,44,46,55-62] Epilepsy and paralysis and impaired consciousness are the symptoms that It is associated with many intracranial lesions and has been reported in COVID-19 patients. Oxygen deprivation, multiple organ failure, or metabolic and electrolyte disturbances may occur. In addition, Guillain-Barré syndrome and Miller-Fisher syndrome are subacute symptoms that are reported 3-10 days after the onset of Covid-19 symptoms in several cases. Have been [63-65]. Several mechanisms may cause heart damage in COVID-19 [66] Cardiac arrhythmia, cardiomyopathy and myocardial injury, heart failure, decreased output have been observed in patients who were severely ill or died of COVID-19 [67-70].
A $78 \%$ prevalence of cardiovascular involvement and myocardial infarction without left ventricular dysfunction in cardiac imaging in COVID-19 patients improved without cardiac symptoms has been reported after hospital discharge [71]. Evidence from the autopsy shows endothelial damage and vascular involvement and a high prevalence of deep vein thrombosis as well as pulmonary arterial thrombosis in COVID-19. Intravenous Thromboembolism (VTE) with a incidence of $25 \%$ and pulmonary embolism with an incidence of $20 \%$ in hospitalized patients is another reason for the deterioration of patients [72-74].

Like other pneumonias requiring hospitalization, acute renal impairment in hospitalized patients with Covid-19 is up to $43 \%$, and with proteinuria and hematuria, AKI is a risk factor for mortality [42] versus mortality in Covid-19 is less common in patients without acute kidney damage. About $15 \%$ of ICU patients develop acute kidney damage. In patients with chronic kidney disease, kidney function may deteriorate. Covid-19 often affects the liver and causes varying degrees of liver dysfunction. [75-77] In a study, 20.4\% of patients with onset of the disease developed skin manifestations that included a wide range of clinical manifestations including macular, papular, maculopapular eruptions, mouth ulcers and blisters [78], and herpetiform lesions [79]. Because skin examinations are often not performed in patients with coronavirus, the prevalence of adverse skin outcomes in COVID-19 patients may be less reported $[80,81]$.

At the time of admission, most patients have at least one underlying disease (diabetes, chronic kidney disease, chronic heart disease, etc.). Treatment potentials include remdesivir, chloroquine, tocilizumab, plasma therapy, and vaccination (if possible) [82].

\section{Covid Can have Destructive Effects on the Pancreas and Kidneys}

According to observations, people with Covid 19 can be exposed to damage to the pancreas (caused by a virus) as a result of diabetes. Long-term observations are needed to determine if the injury will be permanent or if the hyperglycemia is temporary and will resolve over time. In a review of 61 improvements in SARS, Liu et al found that $39.3 \%$ had hypocortisolism and $83.3 \%$ had central adrenal insufficiency. They concluded that adrenal insufficiency could be a late complication of SARS, which could be a secondary consequence of pituitary or direct hypothalamic injury. Other researchers have found central hypothyroidism in SARS survivors, which may be the result of damage to the hypothalamic-pituitary axis [83].

In a cohort study conducted in March 2020 on the effect of viral load on Acute Renal Impairment (AKI) at the time of hospitalization among patients (1049 patients) with sars cov2 in New York City, viral load using instantaneous RT-PCR method was measured and information was extracted by (EHRs). The viral load was associated with an increased risk of AKI.

\section{$(\mathrm{aHR}=1.04,95 \%$ CI: $1.01-1.08, p=0.02)$}

People at the top 50 percent of the viral load were 1.27 times more likely to be infected with AKI than those at the bottom 50 percent. In patients with $\mathrm{AKI}, \mathrm{C}$-reactive protein, procalcitonin, $\mathrm{D}$-dimer, and ferritin levels were significantly higher than the control group and lymphocyte levels were significantly lower than the control group. High levels of viral load at admission may indicate greater disease severity, and strong proinflammatory status, but even after setting inflammatory markers, viral load still showed a strong association with an increased risk of AkI. Lead to the development of AkI, but viral load has a separate and independent role in the development of AKI through other mechanisms [84] 


\section{Respiratory Problems Are one of The Most Common Symptoms of Covid}

Sevim acaroz et al. Wrote an article entitled "Attention to Prevention and Management of Long-Term Consequences of Hot Respiratory Distress Syndrome in Patients with Coronary Artery" with the aim of predicting the complications of coronary heart disease. They have mild coronary but can develop aggressively, leading to acute respiratory syndrome, which can lead to complete bed rest, immobility in patients, and even hospitalization in the ICU.

Focusing on the long-term effects of Acute Respiratory Syndrome has shown that this syndrome leads to hospitalization in the ICU. Weakness and myopia. Based on previous studies of severe acute respiratory distress syndrome and influenza A, we expect that severe dysfunction of the patient's body may occur on the basis of prolonged mechanical ventilation and prolonged stay in intensive care, and this is exactly what happens. It can occur in patients with sars and quid. This phenomenon is characterized by a sudden onset. Decreased muscle strength and muscle mass. Myopathy and neuropathy.

The mentioned complications can bother the patient for a long time, so it is necessary to recognize the coronary complications and acute respiratory syndrome and take the necessary measures to deal with them. [85].

\section{Conclusion}

Most cases are expected to improve and survive this viral outbreak, but the long-term consequences of SARS-CoV-2 infection are unknown. With other serious respiratory illnesses and the wider subsequent intensive care syndrome, it predicted potential long-term consequences. After recovery, patients are at high risk for delayed onset lung disease, heart disease, neurological disorders, weakness, mental health disorders, and even mortality that often persist for months and years after discharge from hospital. Long-term side effects may also occur during COVID-19 and its treatment. These complications are likely to place additional medical, psychological, and economic pressures on all patients. Therefore, there should be a comprehensive post-COVID-19 complication prevention and management plan to suppress their clinical, economic, and public health consequences and to support patients experiencing morbidity and disability as a consequence.

Also, all health care providers (physicians, nurses, and health care workers) should be aware of these complications so that they can be fully evaluated for health care workers and a suitable program can be considered according to the patient's condition and the goals of the treatment team. To achieve such a plan and goals, it is first necessary to identify the lasting effects on coronary arteries in the community and evaluate the frequency and prevalence of each in individuals in the community.

Previous studies on the persistent effects of COVID-19 in different countries have been limited to the statistical population and only due to the persistent effects of COVID-19 on one or two major body systems. In this study, we intend to discuss the wider statistical community as well as more systems of the body and to examine the relationship between the incidence of complications and symptoms in different body systems, age and sex, and underlying diseases. Quality of life and the performance of the recovered after Covid becomes 19.

\section{References}

1. Sinanovic O, Muftic M, Sinanovic S (2020) COVID-19 Pandemia: Neuropsychiatric Comorbidity and Consequences. Psychiatr Danub 32(2): 236-244.

2. Xie M, Chen Q (2020) Insight into 2019 novel coronavirus - An updated interim review and lessons from SARS-CoV and MERS-CoV. Int J Infect Dis 94: 119-124.

3. King AMQ, Adams MJ, Carstens EB, Lefkowitz EJ (2012) Classification and nomenclature of viruses. In: Virus Taxonomy: Ninth Report of the International Committee on Taxonomy of Viruses

4. Ksiazek TG, Erdman D, Goldsmith CS, Zaki SR, Peret T, et al. (2003) A novel coronavirus associated with severe acute respiratory syndrome. $\mathrm{N}$ Engl J Med 348(20): 1953-1966.

5. Sheahan TP, Sims AC, Leist SR, Schafer A, Won J, et al. (2020) Comparative therapeutic efficacy of remdesivir and combination lopinavir, ritonavir, and interferon beta against MERS-CoV.

6. de Groot RJ, Baker SC, Baric RS, Brown CS, Drosten C, et al. (2013) Middle East respiratory syndrome coronavirus (MERS-CoV): announcement of the Coronavirus Study Group. J Virol 87(14): 7790-7792.

7. Zaki AM, van Boheemen S, Bestebroer TM, Osterhaus AD, Fouchier RA (2012) Isolation of a novel coronavirus from a man with pneumonia in Saudi Arabia. N Engl J Med 367(19): 1814-1820.

8. Hascup ER, Hascup KN (2020) Does SARS-CoV-2 infection cause chronic neurological complications? Geroscience 42(4):1083-1087.

9. Meier K, Glatz T, Guijt MC, Piccininni M, van der Meulen M, et al. (2020) Public perspectives on protective measures during the COVID-19 pandemic in the Netherlands, Germany and Italy: A survey study. COVID-19 Survey Study group.

10. Verity R, Okell LC, Dorigatti I, Winskill P, Whittaker C, et al. (2020) Estimates of the severity of coronavirus disease 2019: a model-based analysis. Lancet Infect Dis 20(6):669-677.

11. Q\&A: (2020) Similarities and differences - COVID-19 and influenza.

12. Hung ECW, Chim SSC, Chan PKS, Tong YK, Ng EKO, et al. (2003) Detection of SARS coronavirus RNA in the cerebrospinal fluid of a patient with severe acute respiratory syndrome. Clin Chem 49(12): 21082109.

13. Al-Obaidi MMJ, Bahadoran A, Wang SM, Manikam R, Raju CS, Sekaran SD (2018) Disruption of the blood brain barrier is vital property of neurotropic viral infection of the central nervous system. Acta Virol 62(1):16-27.

14. Michalicova A, Bhide K, Bhide M, Kovac A (2017) How viruses infiltrate the central nervous system. Acta Virol 61(4):393-400.

15. Lau KK, Yu WC, Chu CM, Lau ST, Sheng B, Yuen KY (2004) Possible central nervous system infection by SARS coronavirus. Emerg Infect 10(2): 342-344.

16. Zlateva KT, Van Ranst M (2004) Detection of subgroup B respiratory syncytial virus in the cerebrospinal fluid of a patient with respiratory syncytial virus pneumonia. Pediatr Infect Dis J 23(11):1065-1066.

17. Jiang G, Gong E, Zhang B, Zheng J, Gao Z, Zhong Y, et al (2005) Multiple organ infection and the pathogenesis of SARS. J Exp Med 202(3):415-24.

18. Ding YQ, He L, Zhang QL, Huang ZX, Che XY, Hou JL et al (2004) Organ distribution of severe acute respiratory syndrome (SARS) associated coronavirus (SARS-CoV) in SARS patients: implications for pathogenesis and virus transmission pathways. J Pathol 203(2):622-30.

19. Gerna G, Passarani N, Battaglia M, Rondanelli EG (1985) Human enteric coronaviruses: antigenic relatedness to human coronavirus OC43 and possible etiologic role in viral gastroenteritis. J Infect Dis 151(5):796-803.

20. Jevsnik M, Steyer A, Pokorn M, Mrvic T, Grosek S, et al. (2016) The role of human coronaviruses in children hospitalized for acute bronchiolitis, acute gastroenteritis, and febrile seizures: a 2 -year prospective study. PLoS One 11(5): e0155555.

21. Raj VS, Osterhaus AD, Fouchier RA, Haagmans BL (2014) MERS: emergence of a novel human coronavirus. Nat Med 26(3):317-319.

22. Resta S, Luby JP, Rosenfeld CR, Siegel JD (1985) Isolation and propagation of a human enteric coronavirus. Science 229(4717):978-981. 
23. Riski H, Hovi T (1980) Coronavirus infections of man associated with diseases other than the common cold. J Med Virol 6(3): 259-265.

24. Madjid M, Safavi-Naeini P, Solomon SD, Vardeny O (2020) Potential effects of coronaviruses on the cardiovascular system. JAMA Cardiol 5(7): 831-840.

25. Inciardi RM, Lupi L, Zaccone G, Italia L, Raffo M, Tomasoni D, et al. Cardiac involvement in a patient with coronavirus disease 2019 (COVID-19). JAMA Cardiol 5(7): 819-824.

26. Kakodkar P, Kaka N, Baig MN (2020) A comprehensive literature review on the clinical presentation, and management of the pandemic coronavirus disease 2019 (COVID-19). Cureus 12(4): 7560.

27. Wang L, He W, Yu X, Hu D, Bao M, Liu H, et al (2020) Coronavirus disease 2019 in elderly patients: Characteristics and prognostic factors based on 4-week follow-up. J Infect 80(6): 639-645.

28. Wu Y, Xu X, Chen Z, Duan J, Hashimoto K, Yang L,et al (2020) Nervous system involvement after infection with COVID-19 and other coronaviruses. Brain Behav Immun 87: 18-22.

29. Gupta A, Madhavan M V, Sehgal K, Nair N, Mahajan S, Sehrawat TS, et al (2020) Extrapulmonary manifestations of COVID-19. Na Med 26(7): 1017-1032.

30. Heneka MT, Golenbock D, Latz E, Morgan D, Brown R (2020) Immediate and long-term consequences of COVID-19 infections for the development of neurological disease. Alzheimers Res Ther 12(1): 69.

31. Bandyopadhyay D, Akhtar T, Hajra A, Gupta M, Das A, Chakraborty S, et al (2020) COVID-19 Pandemic: Cardiovascular Complications and Future Implications. Am J Cardiovasc Drugs 20(4): 311-324.

32. Bulfamante G, Chiumello D, Canevini MP, Priori A, Mazzanti M, Centanni S, et al (2020) First ultrastructural autoptic findings of SARSCov-2 in olfactory pathways and brainstem. Minerva Anestesiol. (2020) Minerva Anestesiol 86(6): 678-679.

33. Yuanyuan Z, Jiaman W, Yimin Q, Haibo Y, Weiqu Y, et al. (2020) Comparison of prediction models based on risk factors and retinal characteristics associated with recurrence one year after ischemic stroke. J Stroke Cerebrovasc Dis 29(4)

34. Sinha IP, Harwood R, Semple MG, Hawcutt DB, Thursfield R, Narayan O, et al (2020) COVID-19 infection in children. Lancet Respir Med (85): 446-447.

35. Zhang J, Liu P, Wang M, Wang J, Chen J, Yuan W, et al (2020) The clinical data from 19 critically ill patients with coronavirus disease 2019:a singlecentered, retrospective, observational study Z Gesundh Wiss 21: 1-4.

36. Chen T, Wu D, Chen H, Yan W, Yang D, Chen G, et al (2020) Clinical characteristics of 113 deceased patients with coronavirus disease 2019: retrospective study. BMJ 31: 368

37. D’Amico F, Baumgart DC, Danese S, Peyrin-Biroulet L (2020( Diarrhea during COVID-19 infection: pathogenesis, epidemiology, prevention and management. Clin Gastroenterol Hepatol 18(8): 1663-1672.

38. Zhang X, Chen X, Chen L, Deng C, Zou X, et al. (2020) The evidence of SARS-CoV-2 infection on ocular surface. Ocul Surf 18(3): 360-362.

39. Cavalleri M, Brambati M, Starace V, Capone L, Nadin F, et al. (2020) Ocular features and associated systemic findings in SARS-CoV-2 infection. Ocul Immunol Inflamm 28(6): 916-921.

40. Chan L, Chaudhary K, Saha A, Chauhan K, Vaid A, et al. (2020) AKI in Hospitalized Patients with COVID-19. J Am Soc Nephrol 32(1): 151-160.

41. Hirsch JS, Ng JH, Ross DW, Sharma P, Shah HH, Barnett RL, et al (2021) Acute kidney injury in patients hospitalized with COVID-19. Kidney Int 41(2): 157-163.

42. Mao L, Jin H, Wang M, Hu Y, Chen S, et al. (2020) Neurologic Manifestations of Hospitalized Patients With Coronavirus Disease 2019 in Wuhan, China. JAMA Neurol 77(6): 683-690.

43. Rahman J, Muralidharan A, Quazi SJ, Saleem H, Khan S (2020)
Neurological and Psychological Effects of Coronavirus (COVID-19): An Overview of the Current Era Pandemic. Cureus 12(6): 8460.

44. Suleyman G, Fadel RA, Malette KM, Hammond C, Abdulla H, et al. (2020) Clinical Characteristics and Morbidity Associated With Coronavirus Disease 2019 in a Series of Patients in Metropolitan Detroit. JAMA Netw Open 3(6): 2012270

45. Lechien JR, Chiesa-Estomba CM, De Siati DR, Horoi M, Le Bon SD, et al. (2020) Olfactory and gustatory dysfunctions as a clinical presentation of mild-to-moderate forms of the coronavirus disease (COVID-19): a multicenter European study. Eur Arch Otorhinolaryngol 277(8): 22512261.

46. Puelles VG, Lütgehetmann M, Lindenmeyer MT, Sperhake JP, Wong MN, Allweiss L, et al. (2020) Multiorgan and Renal Tropism of SARSCoV-2. N Engl J Med 383(6): 590-592.

47. Bao Y, Sun Y, Meng S, Shi J, Lu L (2020) 2019-nCoV epidemic: address mental health care to empower society. Lancet 395(10224): 37-38.

48. Troyer EA, Kohn JN, Hong S (2020) Are we facing a crashing wave of neuropsychiatric sequelae of COVID-19? Neuropsychiatric symptoms and potential immunologic mechanisms. Brain Behav Immun 87: 34-39.

49. Lechien JR, Chiesa-Estomba CM, De Siati DR, Horoi M, Le Bon SD, et al. (2020) Olfactory and gustatory dysfunctions as a clinical presentation of mild-to-moderate forms of the coronavirus disease (COVID19): a multicenter European study. Eur Arch Otorhinolaryngol 277(8): 22512261.

50. Sulaiman T, Algharawi AA, Idrees M, Alzaidy RH, Faris K, et al. (2020) The prevalence of gastrointestinal symptoms among patients with COVID-19 and the effect on the severity of the disease. JGH Open 4(6): $1162-1166$

51. Yachou Y, El Idrissi A, Belapasov V, Ait Benali S (2020) Neuroinvasion, neurotropic, and neuroinflammatory events of SARS-CoV-2: understanding the neurological manifestations in COVID-19 patients. Neurol Sci 41(10): 2657-2669.

52. Wang T, Town T, Alexopoulou L, Anderson JF, Fikrig E, et al. (2014) Toll-like receptor 3 mediates West Nile virus entry into the brain causing lethal encephalitis. Nat Med 10(12): 1366-1373.

53. Abboud H, Abboud FZ, Kharbouch H, Arkha Y, El Abbadi N, et al (2020) COVID-19 and SARS-Cov-2 Infection: Pathophysiology and Clinical Effects on the Nervous System. World Neurosurg 140: 49-53.

54. Oxley TJ, Mocco J, Majidi S, Kellner CP, Shoirah H, et al. (2020) Largevessel stroke as a presenting feature of Covid-19 in the young. N Engl J Med 382(20): 60.

55. Ticinesi A, Cerundolo N, Parise A, Nouvenne A, Prati B, et al. (2020) Delirium in COVID-19: epidemiology and clinical correlations in a large group of patients admitted to an academic hospital. Aging Clin Exp Res 32(10): 2159-2166

56. Sheehy LM (2020) Considerations for Postacute Rehabilitation for Survivors of COVID-19. JMIR Public Health Surveill 6(2): 19462.

57. Filatov A, Sharma P, Hindi F, Espinosa PS (2020) Neurological complications of coronavirus disease (COVID-19) Cureus 12(3): 7352.

58. Markus HS, Brainin M (2020) COVID-19 and stroke-A global World Stroke Organization perspective. Int J Stroke 15(4): 361-364.

59. Amalakanti S, Arepalli KVR, Jillella JP (2020) Cognitive assessment in asymptomatic COVID-19 subjects. Virusdisease 32(1): 1-4.

60. Zuberbuhler P, Conti ME, León-Cejas L, Maximiliano-González F, Bonardo P, et al. (2021) Guillain-Barre syndrome associated to COVID-19 infection: a review of published case reports. Rev Neurol 72(6): 203-212

61. Toscano G, Palmerini F, Ravaglia S, Ruiz L, Invernizzi P, et al. (2020) Guillain-Barré Syndrome Associated with SARS-CoV-2. N Engl J Med 382(26): 2574-2576.

62. Gutierrez-Ortiz C, Mendez-Guerrero A, Rodrigo-Rey S, San Pedro- 
Murillo E, Bermejo-Guerrero L, et al. (2020) Miller Fisher syndrome and polyneuritis cranialis in COVID-19. Neurology 95(5): 601-605.

63. Williamson EJ, Walker AJ, Bhaskaran K, Bacon S, Bates C, et al. (2020) Factors associated with COVID-19-related death using OpenSAFELY. Nature 584(7821): 430-436.

64. Liu D, Zhang W, Pan F, Li L, Yang L, et al. (2020) The pulmonary sequalae in discharged patients with COVID-19: a short-term observational study. Respir Res 21(1): 125.

65. Xu XW, Wu XX, Jiang XG (2020) Clinical findings in a group of patients infected with the 2019 novel coronavirus (SARS-Cov-2) outside of Wuhan, China: retrospective case series. JAMA 11: 1061-1069

66. Madjid M, Safavi-Naeini P, Solomon SD, Vardeny O (2020) Potential Effects of Coronaviruses on the Cardiovascular System: A Review. JAMA Cardiol 5(7): 831-840.

67. Wang L, He W, Yu X, Hu D, Bao M, Liu H, et al (2020) Coronavirus disease 2019 in elderly patients: Characteristics and prognostic factors based on 4-week follow-up. J Infect 80(6): 639-645.

68. Puntmann VO, Carerj ML, Wieters I, Fahim M, Arendt C, et al. (2020) Outcomes of Cardiovascular Magnetic Resonance Imaging in Patients Recently Recovered From Coronavirus Disease 2019 (COVID-19) JAMA Cardiol 5(11): 1265-1273.

69. Helms J, Tacquard C, Severac F, Leonard-Lorant I, Ohana M, et al. (2020) High risk of thrombosis in patients with severe SARS-CoV-2 infection: a multicenter prospective cohort study. Intensive Care Med 46(6): 10891098.

70. Zhang, Chaoping (2020) A precision low-power analog front end in $180 \mathrm{~nm}$ CMOS for wireless implantable capacitive pressure sensors. Integration 70: 151-158.

71. Klok FA, Kruip MJHA, van der Meer NJM, Arbous MS, Gommers DAMPJ, et al. (2020) Incidence of thrombotic complications in critically ill ICU patients with COVID-19. Thromb Res 191: 145-147.

72. Boettler T, Newsome PN, Mondelli MU, Maticic M, Cordero E, et al. (2020) Care of patients with liver disease during the COVID-19 pandemic: EASL-ESCMID position paper. JHEP Rep 2(3): 100113.

73. Needham EJ, Chou SH, Coles AJ, Menon DK (2020 Neurological Implications of COVID-19 Infections. Neurocrit Care 32(3): 667-671.

74. Mao R, Qiu Y, He JS, Tan JY, Li XH, et al. (2020) Manifestations and prognosis of gastrointestinal and liver involvement in patients with COVID-19: a systematic review and meta-analysis. Lancet Gastroenterol Hepatol 5(7): 667-678.

75. Sinadinos A, Shelswell J (2020) Oral ulceration and blistering in patients with COVID-19 Evidence-Based Dentistry 21: 49.

76. Tammaro A, Adebanjo GAR, Parisella FR, Pezzuto A, Rello J (2020) Cutaneous manifestations in COVID-19: the experiences of Barcelona and Rome. J Eur Acad Dermatol Venereol 34(7): 306-307.

77. Novak N, Peng W, Naegeli MC, Galvan C, Kolm-Djamei I, et al. (2021) SARS-CoV-2, COVID-19, skin and immunology - What do we know so far? Allergy 76(3): 698-713.

78. Galvan Casas C, Catala A, Carretero Hernandez G, Rodríguez-Jiménez P, Fernandez-Nieto D, et al. (2020) Classification of the cutaneous manifestations of COVID-19: a rapid prospective nationwide consensus study in Spain with 375 cases. Br J Dermatol 183(1): 71-77.

79. Xie M, Chen Q (2020) Insight into 2019 novel coronavirus - An updated interim review and lessons from SARS-CoV and MERS-CoV. Int J Infect Dis 94: 119-124.

80. Mongiò̀ LM, Barbagallo F, Condorelli RA, Cannarella R, Aversa A, et al. (2020)Possible long-term endocrine-metabolic complications in COVID-19: lesson from the SARS model. Endocrine 68(3): 467-470.

81. Paranjpe I, Chaudhary K, Johnson KW, Jaladanki SK, Zhao S, et al. (2021) Association of SARS-CoV-2 viral load at admission with in-hospital acute kidney injury: A retrospective cohort study. PLoS One 16(2): 0247366.

82. Feng Y, Ling Y, Bai T, Xie Y, Huang J, et al. (2020) COVID-19 with Different Severities: A Multicenter Study of Clinical Features. Am J Respir Crit Care Med 201(11): 1380-1388

83. Herridge MS, Tansey CM, Matte A, Tomlinson G, Diaz-Granados N, et al. (2011) Functional disability 5 years after acute respiratory distress syndrome. N Engl J Med 364(14): 1293-304.

84. Xie J, Tong Z, Guan X, Du B, Qiu H, et al. (2020) Critical care crisis and some recommendations during the COVID-19 epidemic in China. Intensive Care Med 46(5): 837-840.

85. Zhu C, Wu Y, Liu H, Ban Y, Ma X, et al. (2020) Early pulmonary rehabilitation for SARS-CoV-2 pneumonia: Experience from an intensive care unit outside of the Hubei province in China. Heart Lung 49(5): 449450 . 